\title{
Decolorisation of exhausted reactive dye bath using ozonator for reuse
}

\author{
M. Sundrarajan, ${ }^{*}$ G. Vishnu, K. Joseph \\ Centre for Environmental Studies, Anna University, Chennai- 600 025, Tamil Nadu, India
}

Received 23 January 2007; revised 28 February 2007; accepted 10 March 2007; available online 20 March 2007

\begin{abstract}
Exhausted Reactive dye bath samples of Turquoise Blue, Olive Green and Navy Blue shades were collected from cotton knit wear dyeing units in Tirupur. Ozonation was conducted in a column reactor system fed with ozone at the rate of $0.16 \mathrm{~g} / \mathrm{min}$ to assess its efficiency in reducing the color, chemical oxygen demand and total organic carbon. Complete decolorization of the effluent was achieved in 10 min contact time and ozone consumption of $153 \mathrm{mg} /$ L for Turquoise Blue, 128 for Olive Green and 143 for Navy Blue shades effluents respectively. The corresponding COD removal was $43 \%, 44 \%$ and $43 \%$ for the three shades while TOC removal efficiency was $45 \%, 45 \%$ and $40 \%$ respectively. The results from the reusability studies indicate that the dyeing quality was not affected by the reuse of decolorized dye bath for two successive cycles. It is concluded that ozonation is efficient in decolorization of exhausted dye bath effluents containing conventional reactive dyes. However, the corresponding removal of COD from the textile effluent was not significant.
\end{abstract}

Key words: Gas turbine, reheat, recuperator, advanced cycles

\section{INTRODUCTION}

Textile industry is one of the most complex industries among the manufacturing industries. Various textile chemicals such as wetting agents, dyes, surfactants, fixing agents, softeners and many other additives are used in wet processes such as bleaching, dyeing and finishing processes. As a result, textile wet processing plants produce highly polluting wastewater (Ademorotti, 1992; Navarro, 2001; Wang, 2002; Sheng and Chi, 1993). Textile dyeing effluents are intensely colored and known to present extreme variations of $\mathrm{pH}$ and temperature, high COD and Dissolved Solids (Sevinmli and Kinaci, 2002; Sheng and Chen, 1997; Sevimli and Sarikaya, 2002). Strong color of the textile wastewater is the most serious problem of the textile waste effluent. Treatment of wastewater containing reactive dyes is a severe problem for the cotton textile industry (Frank, 1994). Ozonation is perhaps the most advanced method ever attempted for decolourisation of the textile effluents (Snider and Porter, 1994; Beszedits, 1980; Green and Sokol, 1985; Gould and Groff, 1987). It is well known that ozone is a powerful oxidant and its oxidizing potential is nearly twice that of chlorine. The high oxidation potential allows ozone to degrade most organic compounds (Chu and $\mathrm{Ma}$, 2000). Ozone and hydroxyl radical $\left(\mathrm{HO}^{\circ}\right)$ species

\footnotetext{
*Corresponding author, Email: vishnikkam@rediffmail.com Tel.: 091442230 1283; Fax: 0914422354717
}

generated in aqueous solution are able to open aromatic rings. Ozone alone and in combination with UV light, catalyst, ultrasound or activated carbon has been successfully applied to textile industrial effluents (Maggiolo, 2000). The advantage is that ozone can be applied directly in its gaseous state and therefore doesn't increase the volume of wastewater and sludge (Sheng and Chi, 1993). This paper presents the results of the studies on decolorization of medium shade dye bath wastewaters originating from cotton knit wears textile industry by ozonation for potential reuse.

\section{MATERIALS AND METHODS}

The overall schematic of the methodology followed is presented in Fig. 1.

The exhausted dye bath samples of Turquoise Blue, Olive Green and Navy Blue shades were collected from Tirupur textile dyeing industries. The samples were characterized, decolorized by ozonation and reused for dyeing. The studies were repeated in 3 cycles. In all the samples were analyzed for $\mathrm{pH}$, Color, $\mathrm{COD}$ and TOC based on Standard Methods (APHA, 1998).

Ozonation studies were done using an experimental set up consisting of ozonator, oxygen concentrator and bubble column reactor and air diffuser as depicted in Fig. 2. Ozone was generated from concentrated oxygen by Indizone Model Ozone generator. The production capacity of ozone generator is $10 \mathrm{~g} / \mathrm{h}$. A cylindrical 
Borosil glass reactor of $10 \mathrm{~cm}$ diameter and $200 \mathrm{~cm}$ height was used for the ozonation. Silicon tubing was used for the connection between oxygen concentrator and ozone generator. Ozonator to column reactor acrylic tube was used. A tubular cylindrical porous diffuser was connected to the acrylic tube and placed at the bottom of the reactor to transfer ozone gas into aqueous solution. Two reactors containing $2 \mathrm{~L}$ of $2 \%$ KI solution was used to trap the ozone in off gas. Sodium thiosulphate titration procedure (APHA, 1998) was performed to measure the ozone concentration, trapped in the KI solutions from which the ozone dose required for complete decolorization of dye bath was determined. All experiments were performed at ambient temperature $\left(28-30^{\circ} \mathrm{C}\right) .10 \mathrm{~L}$ of the exhausted reactive dye bath (Turquoise Blue, Olive Green, Navy Blue) samples were subjected to ozonation for 10 min contact time at an ozone dose of $0.16 \mathrm{~g} / \mathrm{min}$. The samples that were decolorized during this period were turbid. These were subjected to filtration using 5 micron filter at an operating pressure of 1.0 bar.

The exhausted dye bath and decolorized, samples were analyzed for $\mathrm{pH}$, color, $\mathrm{COD}$ and total organic carbon (TOC) based on Standard Methods (APHA,
1998). Total organic carbon (TOC) of the exhausted dye bath and decolorized dye bath were measured using a TOC analyzer (Micro N/C Model 1997, Analytica Jena, Germany). COD was measured according to Standard Methods (APHA, 1998). Colour of the samples was determined by absorbance measurements using Spekol 1200 model spectrophotometer at three different wavelengths $(436,525$ and $620 \mathrm{~nm})$ based on German method (Frank, 1994). The dye bath samples after decolorization (10 min ozonation + filtration) were used for dyeing $10 \mathrm{~g}$ sample of bleached and fluorescent brightener free knitted cotton fabric in a laboratory dyeing machine. The dyes used in this study, their colour Index generic name, $\lambda_{\max }$, chemical constitution and type are provided in Table 1 . The recipe for the dyeing studies and quantity of dyes for the dyeing of $10 \mathrm{~g}$ knitted cotton fabric is given in Table 2. The dyeing studies were also repeated using tap water and salt for comparison of dyeing quality. A Laboratory dyeing machine with 12 numbers of $250 \mathrm{~mL}$ stainless steel tumblers was used for dyeing. The tumblers were filled with $200 \mathrm{~mL}$ of decolorized dye bath or tap water and heated to $40{ }^{\circ} \mathrm{C}$. The dyestuff and exhausting agent $(\mathrm{NaCl})$ were added in the case of tap water (based on

Table 1: Properties of the dyes used in dyeing studies

\begin{tabular}{|c|c|c|c|c|}
\hline S1. No. & CI Name & $\begin{array}{c}\lambda \max \\
(\mathrm{nm})\end{array}$ & Chemical constitution & Type \\
\hline 1 & $\begin{array}{l}\text { CI Reactive } \\
\text { Red } 120\end{array}$ & 510 & Diazo, Dichlorotriazine & $\begin{array}{l}\text { Salt controllable high } \\
\text { substantivity }\end{array}$ \\
\hline 2 & $\begin{array}{l}\text { CI Reactive } \\
\text { Yellow } 84\end{array}$ & 420 & Diazo, Bisaminochlorotriazine & $\begin{array}{l}\text { Salt controllable high } \\
\text { substantivity }\end{array}$ \\
\hline 3 & $\begin{array}{l}\text { CI Reactive } \\
\text { Blue } 5\end{array}$ & 620 & Diazo, Bis (sulphatoethylsulphonate) & $\begin{array}{l}\text { Alkali controllable low } \\
\text { substantivity }\end{array}$ \\
\hline
\end{tabular}

Table 2: Recipe for reactive dyeing

\begin{tabular}{|c|c|c|}
\hline Sl.No. & Parameter & Values \\
\hline 1 & Shade & $\begin{array}{l}\text { Turquoise Blue, Olive } \\
\text { Green, Navy Blue }\end{array}$ \\
\hline 2 & Weight of Knitted fabric (g) & 10 \\
\hline 3 & Material Liquor ratio & $1: 20$ \\
\hline 4 & $\%$ of Shade & $2.0 \%$ \\
\hline 5 & Dye (mg) & 0.2 \\
\hline 6 & Dyeing time (min) & 90 \\
\hline 7 & $\mathrm{NaCl}(\mathrm{g} / \mathrm{L})$ & $60 *$ \\
\hline 8 & $\mathrm{Na}_{2} \mathrm{CO}_{3}(\mathrm{~g} / \mathrm{L})$ & 15 \\
\hline 9 & Temperature $\left({ }^{\circ} \mathrm{C}\right)$ & $70-80$ \\
\hline
\end{tabular}

* Only for tap water the dyeing recipe) while only dyestuff was added for the decolorized dye bath.

Fabric was wetted and immersed in the dye bath and dyeing was done as temperature gradually increased from $40{ }^{\circ} \mathrm{C}$ to $60{ }^{\circ} \mathrm{C}$ in $30 \mathrm{~min}$. At this temperature, alkali $\left(\mathrm{Na}_{2} \mathrm{CO}_{3}\right)$ was added and dyeing was continued at $80^{\circ} \mathrm{C}$ for $60 \mathrm{mins}$. After dyeing, the fabric was removed from the dye bath and hot wash $\left(90^{\circ} \mathrm{C}\right.$ for $10 \mathrm{~min}$ ) was done twice. Then the fabric was neutralized using $0.1 \mathrm{~g} / \mathrm{L}$ glacial acetic acid at $27-30^{\circ} \mathrm{C}$ for $10 \mathrm{~min}$. Soaping with $2 \mathrm{~g} / \mathrm{L}$ soap solution at $90^{\circ} \mathrm{C}$ for 10 min was done followed by two cold washes at 27-30 ${ }^{\circ} \mathrm{C}$ for $10 \mathrm{~min}$ after which the dyed fabric was air dried.

The dyed fabric was tested for colour strength using UV-Visible Spectrophotometer U-3210 (Make: Hitachi). 
The K/S value as per Kubelka - Munk equation has a linear relationship with the concentration of colorant and is calculated using Eq,

$$
\mathrm{K} / \mathrm{S}=\frac{(1-\mathrm{R})^{2}}{2 \mathrm{R}} ; \text { where } \mathrm{R} \text { is the reflectance }(\%)
$$

Wash fastness of dyed sample was measured using ISO Test 3 (ISO 105-C03: 1989, Geneva) testing method. Dyed fabric sample $(10 \mathrm{~cm} \times 4 \mathrm{~cm})$ was taken, stitched with one of the shorter side of the adjacent bleached fabric and put into the water bath at $60^{\circ} \mathrm{C}$ for $30 \mathrm{~min}$.. Then the specimen was washed with hot water, cold water and dried.

After dyeing (cycle-I), the exhausted dye bath samples from laboratory dyeing were analyzed for $\mathrm{pH}$, color, COD and TOC and subjected to ozonation for 10 min and micron filtration. The decolorized samples were used for dyeing (cycle II) and the procedure repeated once again (cycle III).

\section{RESULTS}

The results of the decolorisation studies are presented in Table 3. The color of Turquoise Blue shade dye bath was reduced by $58 \%, 67 \%$ and $55 \%$ at $436 \mathrm{~nm}$, $525 \mathrm{~nm}$ and $620 \mathrm{~nm}$ respectively at an ozone contact time of 10 minutes. The ozone consumption during the period was $153 \mathrm{mg} / \mathrm{L}$. Micron filtration of this sample improved the over all color removal to 74,75 and $92 \%$ at the three wavelengths. The color of Olive Green was reduced by $98 \%, 63 \%$ and $74 \%$ at $436 \mathrm{~nm}, 525 \mathrm{~nm}$ and $620 \mathrm{~nm}$ respectively at an ozone contact time of 10 minutes. The ozone consumption during the period was $128 \mathrm{mg} / \mathrm{L}$. Micron filtration of this sample improved the over all colour removal to $99 \%, 78 \%$ and $83 \%$ at the three wavelengths respectively. The color of Navy
Blue was reduced by $100 \%, 93 \%$ and $90 \%$ at $436 \mathrm{~nm}$, $525 \mathrm{~nm}$ and $620 \mathrm{~nm}$ respectively at an ozone contact time of 10 minutes (Fig. 5). The ozone consumption during the period was $142.5 \mathrm{mg} / \mathrm{L}$. Micron filtration of this sample improved the over all colour removal to 100,94 and $90 \%$ at the three wavelengths respectively.

The results of the COD and TOC removal by ozonation is presented in Fig. 3. It was observed that the COD removal for Turquoise dye bath was $29 \%$ while TOC removal was $32 \%$. Micron filtration improved it to $43 \%$ for COD and $45 \%$ for TOC removal. It was observed that the COD removal $(31 \%)$ and TOC removal (31\%) for Olive Green dye bath was low at a contact time of 10 minutes. Micron filtration improved it by $44 \%$ for COD and $45 \%$ for TOC removal. It was observed that the COD removal $(27 \%)$ and TOC removal (21\%) for Navy Blue dye bath was low at a contact time of 10 minutes. Micron filtration improved it by $43 \%$ for COD and $40 \%$ for TOC removal. The results of the decolorisation studies are for cycle II and III are presented in Tables 4 and 5. For cycle II, decolorization of $57 \%, 67 \%$ and $57 \%$ was observed for Turquoise Blue shade dye bath, at $10 \mathrm{~min}$ contact time which increased to $71 \%, 73 \%$ and $71 \%$ at 436 , $525,620 \mathrm{~nm}$ respectively after micron filtration. A similar increase was observed for cycle III.

For Olive Green dye bath, at 10 min contact time decolorization of $98 \%, 67 \%$ and $79 \%$ was observed which increased to $98 \%, 74 \%$ and $82 \%$ at $436,525,620$ $\mathrm{nm}$ respectively after micron filtration for cycle II. A similar increase was observed for cycle III. For Navy Blue dye bath, at 10 min contact time decolorization of $100 \%, 91 \%$ and $90 \%$ was observed which increased to $100 \%$ at $436,525,620 \mathrm{~nm}$ respectively after micron filtration for cycle II.

\begin{tabular}{|c|c|c|c|c|c|c|c|c|c|}
\hline \multirow{2}{*}{ Time } & \multicolumn{3}{|c|}{ Turquoise Blue } & \multicolumn{3}{|c|}{ Olive Green } & \multicolumn{3}{|c|}{ Navy Blue } \\
\hline & $436 \mathrm{~nm}$ & $525 \mathrm{~nm}$ & $620 \mathrm{~nm}$ & $436 \mathrm{~nm}$ & $525 \mathrm{~nm}$ & $620 \mathrm{~nm}$ & $436 \mathrm{~nm}$ & $525 \mathrm{~nm}$ & $620 \mathrm{~nm}$ \\
\hline 1 & 11 & 50 & 20 & 8 & 8 & 10 & 9 & 7 & 15 \\
\hline 2 & 16 & 50 & 22 & 16 & 10 & 12 & 22 & 26 & 33 \\
\hline 3 & 16 & 50 & 24 & 45 & 12 & 20 & 84 & 83 & 48 \\
\hline 4 & 21 & 58 & 25 & 83 & 32 & 31 & 84 & 85 & 63 \\
\hline 5 & 26 & 58 & 27 & 93 & 48 & 49 & 91 & 88 & 65 \\
\hline 6 & 32 & 58 & 28 & 96 & 52 & 53 & 97 & 90 & 68 \\
\hline 7 & 37 & 67 & 30 & 96 & 53 & 54 & 98 & 91 & 69 \\
\hline 8 & 42 & 67 & 39 & 89 & 61 & 63 & 100 & 91 & 87 \\
\hline 9 & 47 & 67 & 46 & 98 & 67 & 70 & 100 & 92 & 88 \\
\hline 10 & 58 & 67 & 55 & 98 & 63 & 74 & 100 & 93 & 90 \\
\hline $10+F^{*}$ & 74 & 75 & 92 & 99 & 78 & 83 & 100 & 94 & 90 \\
\hline
\end{tabular}

Table 3: Decolourisation (\%) of reactive dyebaths by ozonation for Cycle 1 
Decolorisation of exhausted reactive dye bath using ozonator for reuse

Table 4: Decolourisation (\%) of reactive dyebaths by ozonation for Cycle 2

\begin{tabular}{cccccccccc}
\hline & \multicolumn{4}{c}{ Turquoise } & \multicolumn{3}{c}{ Olive } & \multicolumn{3}{c}{ Navy } \\
Time & 436 & 525 & 620 & 436 & 525 & 620 & 436 & 525 & 620 \\
& $\mathrm{~nm}$ & $\mathrm{~nm}$ & $\mathrm{~nm}$ & $\mathrm{~nm}$ & $\mathrm{~nm}$ & $\mathrm{~nm}$ & $\mathrm{~nm}$ & $\mathrm{~nm}$ & $\mathrm{~nm}$ \\
\hline 1 & 5 & 13 & 19 & 2 & 6 & 11 & 6 & 3 & 15 \\
2 & 10 & 47 & 23 & 9 & 10 & 20 & 15 & 23 & 33 \\
3 & 14 & 53 & 39 & 14 & 12 & 33 & 65 & 81 & 48 \\
4 & 19 & 60 & 43 & 38 & 19 & 42 & 71 & 84 & 63 \\
5 & 24 & 60 & 43 & 69 & 24 & 47 & 79 & 87 & 65 \\
6 & 29 & 67 & 43 & 94 & 33 & 59 & 86 & 90 & 68 \\
7 & 43 & 67 & 43 & 95 & 51 & 64 & 90 & 90 & 69 \\
8 & 48 & 67 & 43 & 94 & 55 & 69 & 95 & 91 & 87 \\
9 & 52 & 67 & 51 & 97 & 59 & 74 & 96 & 91 & 88 \\
10 & 57 & 67 & 57 & 98 & 67 & 79 & 100 & 91 & 90 \\
$10+$ & & & & & & & & & \\
$\mathrm{F}$ & 71 & 73 & 77 & 98 & 74 & 82 & 100 & 100 & 100 \\
\hline
\end{tabular}

A similar increase was observed for cycle III.

From the results of COD and TOC removal resented in Figure 4 and 5, it is observed that for Olive Green dyebath, TOC and COD removal was $32 \%$ in the second cycle, which further increased to $45 \%$ on micronfiltration. For Olive green dyebath, the $\mathrm{COD} /$ TOC reduction was $30 \%$, which increased to $44 \%$ on micronfiltration. A similar observation for navy blue shade was also seen. A similar trend was seen for third cycle with the TOC/COD removal ranging between 25 $\%$ to $34 \%$ and increasing to $42 \%$ to $45 \%$ after micron filtration. The $\mathrm{K} / \mathrm{S}$ value and wash fastness of the fabric dyed with tap water and decolorized dye bath obtained in the the different cycles is presented in Table 6 . The first cycle showed little variation with a difference of 0.0038 for Turquoise Blue, 0.0057 for Olive Green and 0.0027 for Navy Blue shade. A similar trend was observed for wash fastness, as the grey scale value of tap water when compared with the three shades did not show variation. When the $\mathrm{K} / \mathrm{S}$ value of the fabric dyed with tap water and decolorized dye bath obtained from cycle II and III were compared, there was a significant deterioration of quality in cycle III. The difference was 0.0058 for cycle II and 0.0598 for cycle III for Turquoise Blue, 0.0077 for cycle II and 0.1625 for cycle III for Olive Green and 0.0053 and 0.0896 for cycle II and III for Navy Blue shade respectively. A similar trend was observed for wash fastness, as the grey scale value was lower for cycle III when compared with other shades/ cycles. Cycle II and I produced good wash fastness when compared to cycle III.
Table 5: Decolourisation (\%) of reactive dyebaths by ozonation for Cycle 3

\begin{tabular}{cccccccccc}
\hline & \multicolumn{3}{c}{ Turquoise } & \multicolumn{3}{c}{ Olive } & \multicolumn{3}{c}{ Navy } \\
Time & 436 & $\begin{array}{c}\text { Blue } \\
525\end{array}$ & 620 & 436 & 525 & 620 & 436 & 525 & 620 \\
& $\mathrm{~nm}$ & $\mathrm{~nm}$ & $\mathrm{~nm}$ & $\mathrm{~nm}$ & $\mathrm{~nm}$ & $\mathrm{~nm}$ & $\mathrm{~nm}$ & $\mathrm{~nm}$ & $\mathrm{~nm}$ \\
\hline 1 & 5 & 50 & 20 & 2 & 6 & 11 & 6 & 3 & 15 \\
2 & 11 & 50 & 22 & 9 & 10 & 20 & 15 & 23 & 33 \\
3 & 16 & 50 & 24 & 14 & 12 & 33 & 65 & 81 & 48 \\
4 & 21 & 58 & 25 & 38 & 19 & 42 & 71 & 84 & 63 \\
5 & 26 & 58 & 27 & 69 & 24 & 47 & 79 & 87 & 65 \\
6 & 32 & 58 & 28 & 94 & 33 & 59 & 86 & 90 & 68 \\
7 & 37 & 67 & 30 & 95 & 51 & 64 & 90 & 90 & 69 \\
8 & 42 & 67 & 39 & 94 & 55 & 69 & 95 & 91 & 87 \\
9 & 47 & 67 & 46 & 97 & 59 & 74 & 96 & 91 & 88 \\
10 & 58 & 67 & 55 & 97 & 61 & 75 & 95 & 91 & 90 \\
$10+$ & & & & & & & & & \\
$\mathrm{F}$ & 74 & 75 & 92 & 98 & 68 & 79 & 96 & 92 & 90 \\
\hline
\end{tabular}

\section{DISCUSSION AND CONCLUSION}

These results are in line with the decolorisation efficiency of 95\% (Balcioglu and Arslan, 2001), $71 \%$ (Ramasamy et al., 2001) and $90 \%$ at 5 min ozonation time (Assalin, et al., 2004) at ozone dose of 15 and $14 \mathrm{~g} / \mathrm{L}$ respectively. Complete color removal of dye bath at 60 min ozonation time has also been reported (Balcioglu and Arslan, 2001; Arslan, 2000) at an ozone dose of 35 $\mathrm{mg} / \mathrm{L}$. For Navy blue shade, micron filtration did not have any effect for increasing color removal while for Olive green and turquoise blue shades there was a significant increase in color removal after micron filtration. It was reported (Oguz et al., 2005) that though ozonation is an efficient process for dye removal, COD removal was rather inefficient, usually not exceeding $54 \%$. The reduction of COD and TOC for Turquoise Blue, Olive Green and Navy Blue shade dye bath was low and did not show much variation. Approximately a reduction of 40-45\% COD was achieved after 10 minutes of ozonation followed by micron filtration. This was comparable with the reported values for COD reduction of 11-29\% (Perkowski, et al., 2000), $50 \%$ (Selcuk, 2005), 27-87 \% (Wu and Wang, 2001) and 5-20 $\%$ (Frank, 1994) respectively. A TOC reduction of $5 \%$ at $5 \mathrm{~min}$ contact time and $43 \%$ at $60 \mathrm{~min}$ contact time was reported (Balcioglu and Arslan, 2001). In other studies, $50 \%$ TOC removal (Ince and Tezcanli, 2001) and $48-62 \%$ removal at $5 \mathrm{~min}$ contact time has been reported (Arslan and Balcioglu, 2000). The increase in COD and TOC in successive cycles could be attributed to increased residual by-products of ozonation with each cycle of reuse. The increase in TOC removal after 
Int. J. Environ. Sci. Tech., 4 (2): 263-270, 2007

Table 6: K/S and wash fastness of dyed fabrics

\begin{tabular}{|c|c|c|c|c|c|}
\hline \multirow{2}{*}{ Sl.No. } & \multirow{2}{*}{ Reuse cycle } & \multirow{2}{*}{ Shade } & \multirow{2}{*}{$\mathrm{K} / \mathrm{S}$} & \multicolumn{2}{|c|}{ Wash fastness } \\
\hline & & & & Change in shade & Change in stain \\
\hline \multirow[t]{6}{*}{1} & & Turquoise & & $4-5$ & $4-5$ \\
\hline & & Blue & 0.5563 & & \\
\hline & Standard & Olive & & 5 & 5 \\
\hline & (Tap Water) & Green & 0.7754 & & \\
\hline & & Navy & & 5 & 5 \\
\hline & & Blue & 0.7911 & & \\
\hline \multirow[t]{6}{*}{2} & & Turquoise & & 4 & 4 \\
\hline & & Blue & 0.5525 & & \\
\hline & Cycle 1 & Olive & & 5 & 5 \\
\hline & & Green & 0.7703 & & \\
\hline & & Navy & & 5 & 5 \\
\hline & & Blue & 0.7884 & & \\
\hline \multirow[t]{6}{*}{3} & & Turquoise & & $3-4$ & $3-4$ \\
\hline & & Blue & 0.5505 & & \\
\hline & Cycle 2 & Olive & & 4 & 4 \\
\hline & & Green & 0.7677 & & \\
\hline & & Navy & & 4 & 4 \\
\hline & & Blue & 0.7858 & & \\
\hline \multirow[t]{6}{*}{4} & & Turquoise & & $2-3$ & $2-3$ \\
\hline & & Blue & 0.4965 & & \\
\hline & Cycle 3 & Olive & & 3 & 3 \\
\hline & & Green & 0.6129 & & \\
\hline & & Navy & & 3 & 3 \\
\hline & & Blue & 0.7015 & & \\
\hline
\end{tabular}

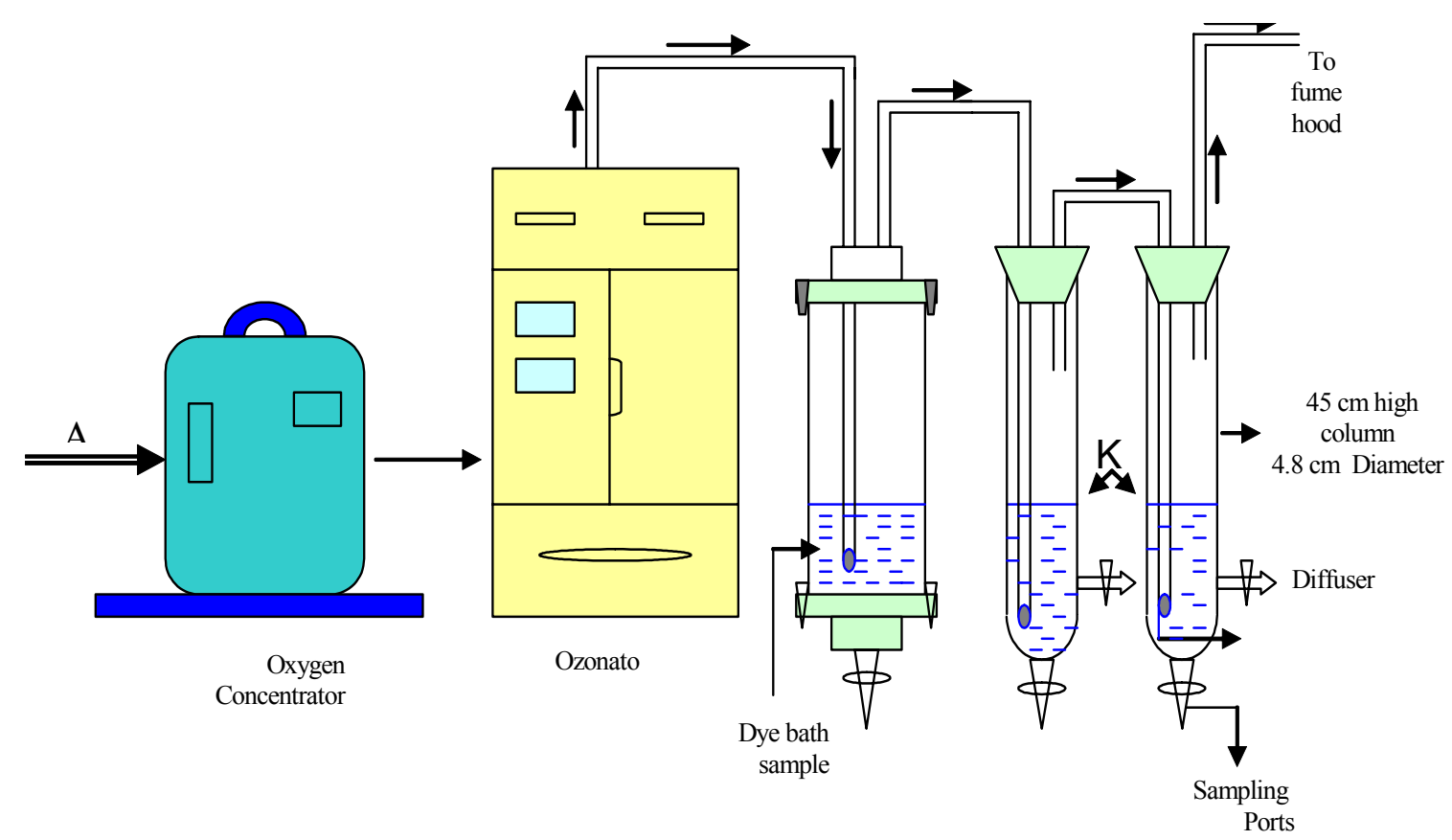

Fig. 1: Experimental setup for ozonation 
M. Sundrajan, et al.

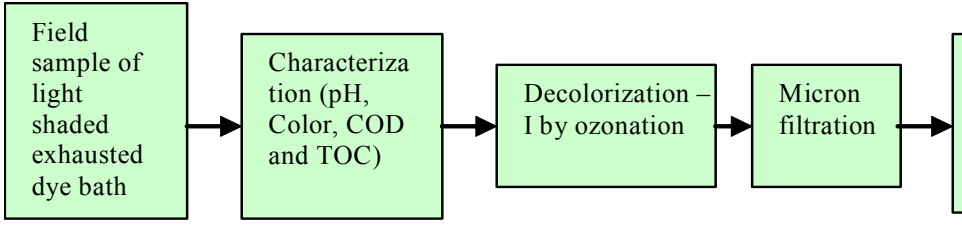

Cycle 1
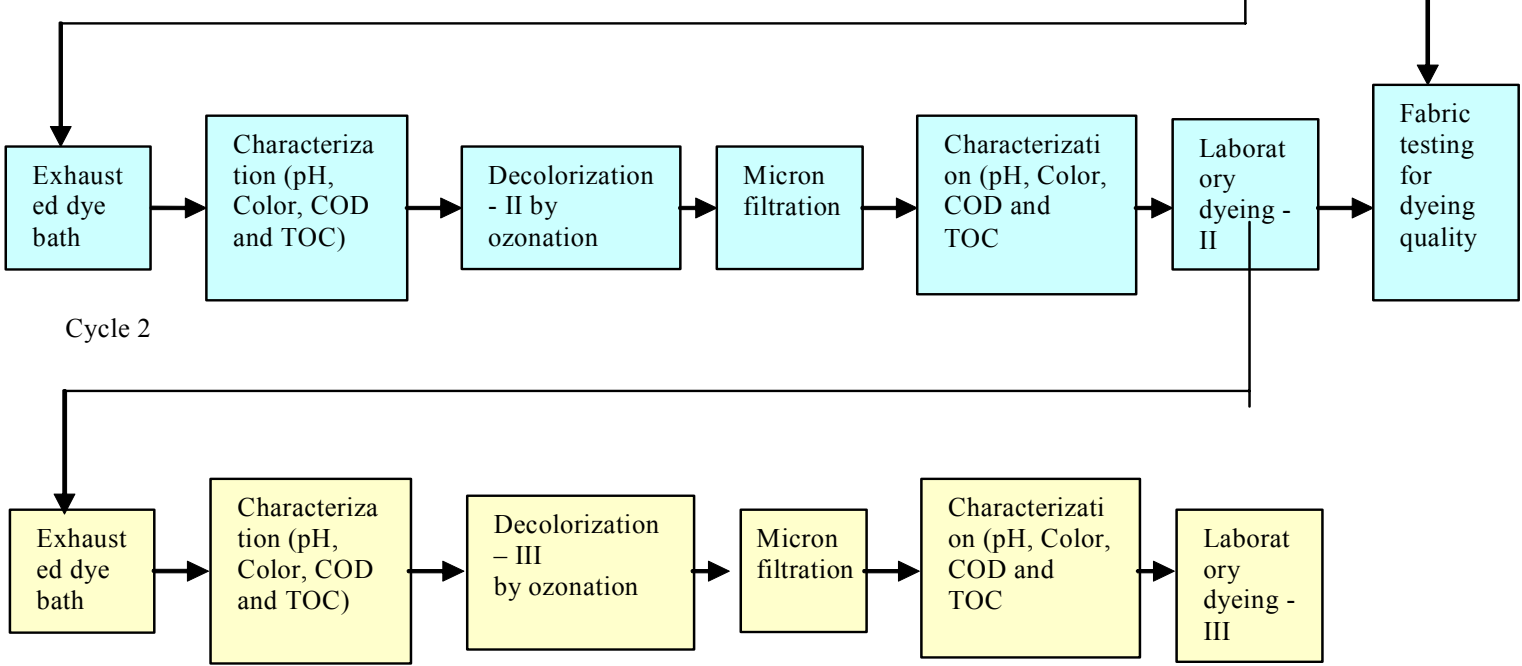

Cycle 3 Fig. 2: Schematic of methodology for decolorization and reuse of reactive dye bath

micron filtration is from the reason that the organic particulate matter causing turbidity and contributing to the TOC/COD of the effluent is removed. Significantly the high COD and TOC of the decolorized dye bath obtained in the first cycle I did not affect the quality of the subsequent dyeing, while the increase of COD and TOC in the cycle II affected the quality of the third cycle. The results of the present studies show that ozonation is effective in complete decolorisation of exhausted dye bath effluent. The associated COD and TOC reduction was low. At a contact time of 10 minutes and ozone consumption of $153 \mathrm{mg} / \mathrm{L}$ for Turquoise Blue, $128 \mathrm{mg} / \mathrm{L}$ for Olive Green and $143 \mathrm{mg} /$ L for Navy Blue, $78-100 \%$ of color removal was achieved. Micron filtration played an important role in removing the turbidity that interfered with color measurement. The average COD removal, for the Turquoise blue, Olive Green and Navy Blue shades of exhausted reactive dye bath was $44 \%$ while TOC removal was in the range of $40-45 \%$. This was similar to the COD removal efficiency for light shades achieved at less ozonation time. This implies that ozonation alone, is not a satisfactory method for removal of COD and TOC. Though the color is removed effectively, the by- products are still present in the decolorized dye bath and contribute to COD and TOC. As micron filtration improved the TOC removal of the ozonated effluent it can be included as a postreatment step after ozoantion.

The results from the reusability studies of decolorized dye bath indicate that the dyeing quality was not affected for two successive cycles. The increase in residual COD and TOC affected the dyeing quality in the third cycle implying that ozonation was feasible for decolorisation of medium shaded dye bath for two cycles of reuse. This is in line with the results obtained from decolorisation and reuse of light shade dye bath. Further TOC/COD reduction is needed for its repeated reuse in more than two dyeing cycles.

\section{ACKNOWLEDGEMENT}

The authors are thankful to the Ministry of Environment and Forests (MoEF), Govt. of India, for funding the research project. 


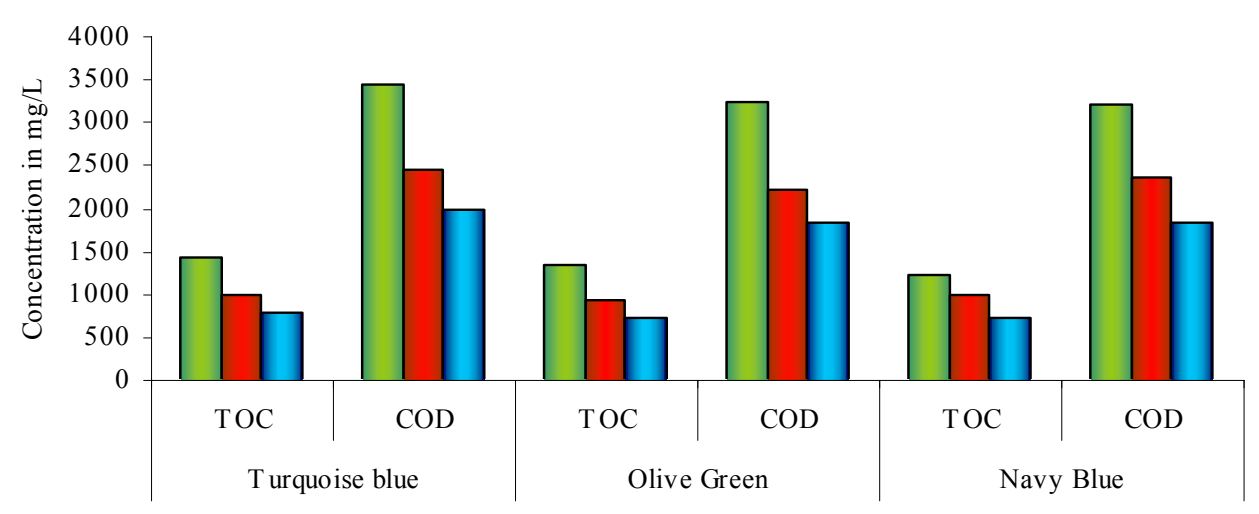

Fig. 3: COD and TOC removal by ozonation for Cycle I

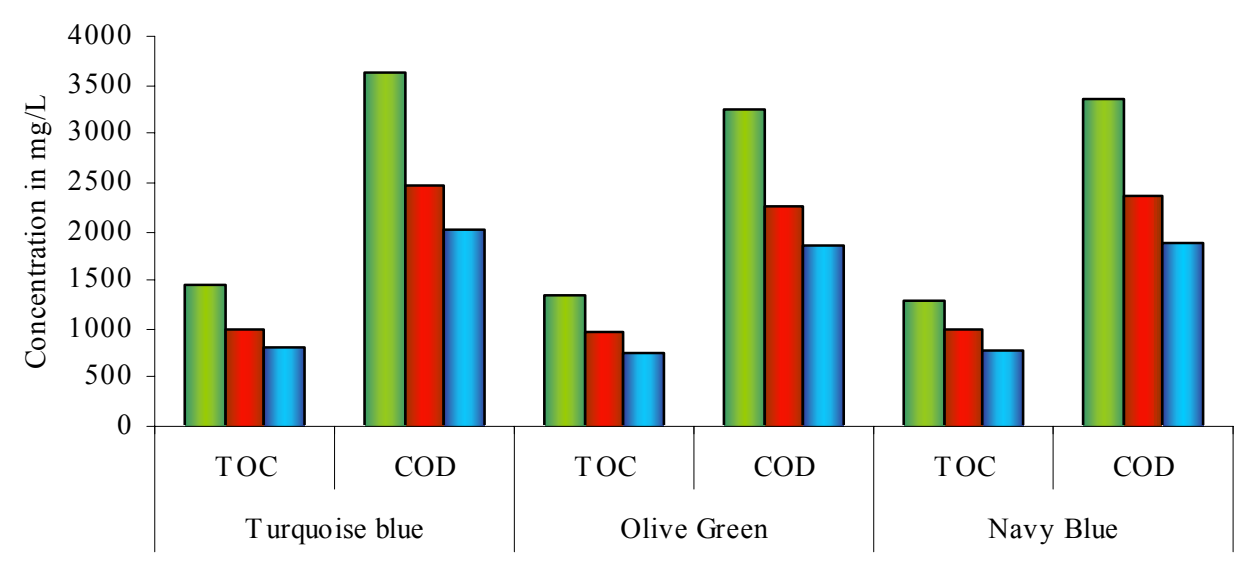

Fig. 4. COD and TOC removal by ozonation for Cycle II

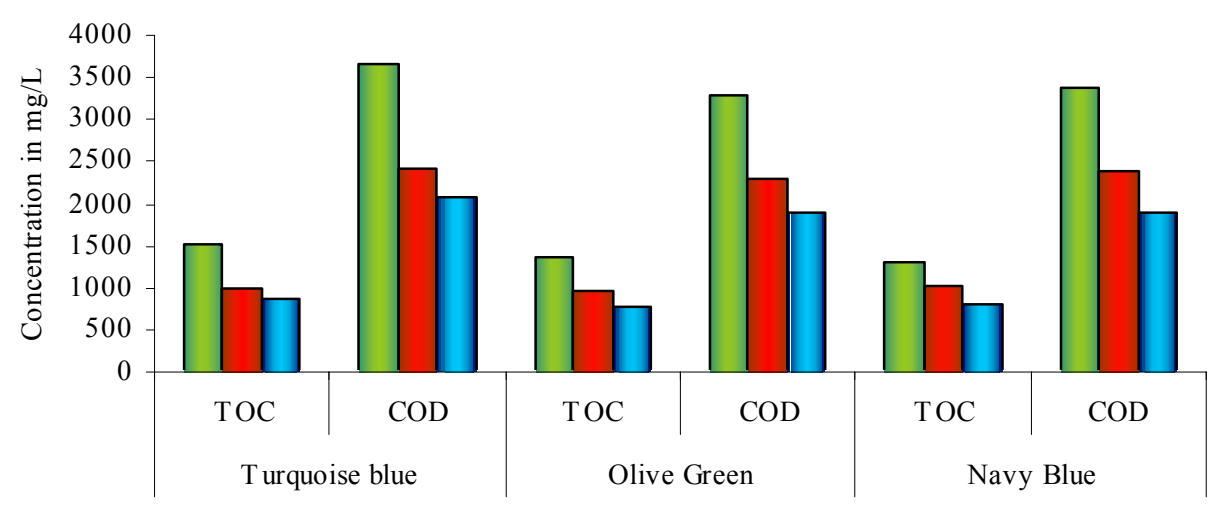

$\square$ Exhausted dyebath $\square$ Decolorised dyebath $\square$ Dyebath after micron filtration

Fig. 5. COD and TOC removal by 


\section{REFERENCES}

Ademorotti C.M.A., (1992). Studies of textile effluent discharges, Int. J Environ Stud., 38, 291-296.

American Public Health Association., (1998). Standard method for the examination of water and wastewater. $20^{\text {th. }}$ Ed. Washington, DC. American Public Health Association.APHA/AWWA/WPCF.

Arslan, I., Balcioglu, A., (2000). Effect of common reactive dye auxiliaries on the ozonation of dye house effluents containing vinylsulphone and aminochlorotriazine dyes. Desalination. 130, 61-71.

Arslan, I., (2000). Advanced treatment of dyehouse effluents by $\mathrm{Fe}(\mathrm{II})$ and $\mathrm{Mn}(\mathrm{II})$ - catalysed ozonation and the $\mathrm{H}_{2} \mathrm{O}_{2} / \mathrm{O}_{3}$ process. Water Sci. Technol., 42, 13-18.

Assalin M.R., Almeida, E.S., Rosa, M.A., Moraes, S.G., Duran, N., (2004). Application of ozonation process in industrial wastewaters: textile, Kraft and whey effluents. Environ Technol., 25, 867-872.

Balcioglu, I.A., Arslan, I., (2001). Partial oxidation of reactive dyestuffs and synthetic textile dye bath by the $\mathrm{O}_{3}$ and $\mathrm{O}_{3} /$ $\mathrm{H}_{2} \mathrm{O}_{2}$ processes. Water Sci. Technol., 43, 221-228.

Beszedits, S., (1980). Ozonation to decolourise textile effluents. Am. Dyest. Rep., 69-38.

Chu, W., Ma, C., (2000). Quantitative prediction of direct and indirect dye ozonation kinetics. Water Res., 34, 3153-3160.

Frank, G., Hermanutz, F., Oppermann, W., (1994). Ozonation - an important technique to comply with new german laws for textile wastewater treatment. Water Sci. Technol., 30, 225-236.

Gould, J.P., Groff, K.A., (1987). Kinetics of ozonolysis of synthetic dyes. Ozone Sci. Eng. 9, 153.

Green, J.M., Sokol, C., (1985). Using ozone to declourize dyeing plant wastewater. Am. Dyest. Rep., 74, 67.

Ince, N.H., Tezcanli, G., (2001). Reactive dyestuff degradation by combined sonolysis and ozonation. Dyes Pigments. 49, $145-53$.

Maggiolo, A., (2000). The present and future of ozone treatment of textile wastes in conjunction with exchange resins or lime. In: Proceedings of the American association textile chemists and colorists environment symposium, Atlanta, Georgia; March, 29,30.

Navarro, V.A., (2001). Determination of wastewater Lc50 of the different process stages of the textile industry. Ecotoxicol. Environ. Saf., 48, 56-61.

Oguz, E., Keskinler, B., Celik, Z., (2005). Ozonation of aqueous Bomaplex Red CR-L dye in a semi-batch reactor. Dyes Pigments. 64, 101-108.

Perkowski, J., Kos, L., Ledakowicz, S., (2000). Advanced oxidation of textile wastewaters. Ozone Sci. Eng., 22, 53550 .

Ramasamy R.K., Rahman N.A. and San W.C. (2001). Effect of temperature on the ozonation of textile waste. Color. Tech. 117, 95-97.

Selcuk, H., (2005). Decolorization and detoxification of textile wastewater by ozonation and coagulation processes. Dyes and Pigments., 64, 217-222.

Sevimli, M.F., Sarikaya, H.Z., (2002). Ozone treatment of textile effluents and dyes: effect of applied ozone dose $\mathrm{pH}$ and dyes concentration. J. Chem. Technol. Biotechnol., 77, 842-850.

Sevinmli, M.F., Kinaci, C., (2002). Decolourization of textile by ozonation and Fenton's process. Water Sci. Technol., 45, 279-286.

Sheng, H.L., Chi, M.L., (1993). Treatment of textile waste effluents by ozonation and chemical coagulation. Wat Res., 27, 1743-1748.

Sheng, H.L., Chen, M.L., (1997). Treatment of textile wastewater by chemical methods for reuse. Water Research. 31, 868-876.

Snider, E.H., Porter, J.J., (1994). Ozone treatment of textile wastes. J. Water Pollut. Control Fed., 46, 886.

Wang C. (2002), Toxicity evaluation of reactive dyestuffs, auxiliaries and selected effects in textile finishing industry to luminescent bacteriaVibrio fischeri. Chemosphere. 46, 339-344.

Wu J., Wang, T., (2001). Ozonation of aqueous azo dye in a semi batch reactor. Water Res., 35, 1093-1099.

\section{AUTHOR (S) BIOSKETCHES}

Sundrarajan, M., Ph.D., Research associate, Centre for Environmental Studies, Anna University, Chennai600, 025. Tamil Nadu, India. Email: sundrarajan@yahoo.com

Vishnu, G., M.Sc., Research scholar, Centre for Environmental Studies, Anna University, Chennai-600 025. Tamil Nadu, India. Email: vishnikkam@rediffmail.com

Joseph, K., M.Tech, Ph.D., Assistant professor, Centre for Environmental Studies, Anna University, Chennai600 025, Tamil Nadu, India. Email: kuttiani@vsnl.com

This article should be referenced as follows:

Sundrarajan, M., Vishnu, G., Joseph, K.,(2007). Decolorisation of exhausted reactive dye bath using ozonator for reuse. Int. J. Environ. Sci. Tech., 4 (2), 263-270. 